\title{
Selective Growth Inhibition of Cancer Cells by L-Methioninase-Containing Fusion Protein Targeted to the Urokinase Receptor
}

\author{
Naveen R. Palwai ${ }^{a} \quad$ Xiao-Ping Zang ${ }^{b}$ Roger G. Harrison ${ }^{a}$ Doris Benbrook ${ }^{c}$ \\ J. Thomas Pento ${ }^{\text {b }}$ \\ aBioengineering Center and School of Chemical, Biological and Materials Engineering, University of Oklahoma, \\ Norman, Okla., ${ }^{b}$ Department of Pharmaceutical Sciences, College of Pharmacy, and 'Department of Obstetrics and \\ Gynecology and Department of Biochemistry and Molecular Biology, College of Medicine, University of Oklahoma \\ Health Sciences Center, Oklahoma City, Okla., USA
}

\section{Key Words}

Ovarian cancer $\cdot$ Skin cancer $\cdot$ Breast cancer $\cdot$ Pancreatic cancer $\cdot$ Methioninase $\cdot$ Urokinase $\cdot$ Cancer targeting $\cdot$ Fusion protein

\begin{abstract}
Background: We have reported the development of a novel fusion protein (FP) consisting of an amino-terminal fragment of urokinase linked to the amino terminus of the enzyme Lmethioninase (L-M). The present study compared the effect of this novel FP on the proliferation of human ovarian, skin, breast endometrial and pancreatic cancer cell lines. Methods: The FP, L-M and a mutated FP, with reduced L-M activity, were produced by recombinant methods. The effect of treatment with FP, L-M and mutated FP on the proliferation of the cancer cells was measured in vitro using an MTS assay. $\boldsymbol{R e}$ sults: The inhibitory effect of the FP was found to be significantly greater than that of L-M alone or the mutated FP. In addition, the FP produced a greater inhibitory effect on an ovarian cancer cell line than on comparable normal, noncancerous cells. Further, the FP produced a dose-dependent inhibition of the proliferation of pancreatic cancer cell lines. Conclusion: These results suggest that this FP is a potent
\end{abstract}

\section{KARGER}

() 2009 S. Karger AG, Base

Fax +41613061234 E-Mail karger@karger.ch www.karger.com www.karger.com/pha and selective inhibitor of the proliferation of various cancer cell lines and has potential as a therapeutic agent for the treatment of various methionine-dependent cancers.

Copyright $\odot 2009$ S. Karger AG, Basel

\section{Introduction}

A major problem with current chemotherapeutic drugs for cancer is a lack of specificity, resulting in undesirable side effects. Significant current effort in cancer research is being devoted to designing new types of chemotherapy that use the properties of cancer cells that are unique compared to normal cells. A unique property of many types of cancer cells is methionine dependence [1, 2]; this property results in cells being unable to proliferate or survive when the amino acid methionine is depleted from the media or replaced with homocysteine (Hcy). By contrast, normal adult cell lines survive and grow well with Hcy.

One approach to produce methionine depletion for the treatment of cancer is the use of the enzyme L-methioninase (L-M), which was first reported in 1973 [3]. Later studies of L-M injected intraperitoneally in nude

J. Thomas Pento, $\mathrm{PhD}$

Department of Pharmaceutical Sciences

University of Oklahoma Health Sciences Center

1110 N. Stonewall Ave., Oklahoma City, OK 73117 (USA)

Tel. +1 405271 6593, Fax +1 405271 7505, E-Mail tom-pento@ouhsc.edu 
mice showed effective inhibition of the Yoshida sarcoma and a human lung tumor with only minimal toxicity [4]. These studies were followed by a phase I clinical trial in which L-M was infused intravenously for $24 \mathrm{~h}$ to $9 \mathrm{pa}-$ tients with either advanced lung, breast or kidney cancer, or lymphoma, which resulted in the reduction of serum methionine to very low levels, with no adverse side effects [5].

To develop a more effective L-M cancer treatment with greater cancer cell selectivity and less cytotoxicity, utilizing less enzyme and shorter treatment periods, a fusion protein (FP) was designed consisting of an aminoterminal fragment of human urokinase (ATF, amino acids 1-49) linked to the amino-terminus of L-M [6]. ATF is included in the FP in order for L-M to be targeted to the urokinase receptor, which is overexpressed by many cancer cells [7-13] and which is found concentrated at the invasive foci of most types of human cancer [14]. Urokinase is responsible for the generation of plasmin, which is involved in the process of extracellular matrix degradation, a process that is critical for cancer metastasis. The part of urokinase with catalytic activity was not included in the FP in order to avoid increased metastasis. The A chain of urokinase has been shown to be responsible for binding to the receptor [15], and residues 12-32 in the A chain have been found to be critical for receptor binding [16]. Another important finding is that the amino-terminal fragment of the A chain by itself is not internalized, since the $B$ chain is required for internalization [17].

Our previous studies with this FP in breast cancer demonstrated that the FP binds specifically to the urokinase receptor of MCF-7 cells in vitro [6, 18]. Moreover, the FP produced a dose-dependent inhibition of both the proliferation and migration of MCF-7 cells in vitro and a reduction in the growth of MCF-7 tumor xenografts in vivo [18].

Because of our earlier promising results with this FP in breast cancer cells, the present study was designed to examine the influence of the FP on skin, ovary, breast and pancreatic cancer cells, and to determine its cancer specificity by comparing its effects on a normal and cancerous ovarian cell line.

\section{Materials and Methods}

Construction, Expression and Purification of Recombinant Proteins

Escherichia coli host strain BL21(DE3), harboring the genes for FP, mutated FP (Y114F mutation), or L-M, was employed for the expression of the three recombinant proteins used in this study.
The construction, expression and purification of the proteins used in this study were accomplished as described elsewhere [18]. The mutation eliminated methioninase activity in the FP. DNA sequences were verified by sequencing at the Oklahoma Medical Research Foundation (Oklahoma City, Okla., USA). Amino-terminal protein sequencing was performed by the Molecular Biology Resource Facility at the University of Oklahoma Health Sciences Center.

\section{Cell Culture}

A375 (skin), A2780 (ovarian), MCF-7 (breast), Paca-1 and HPAF-II (pancreatic) human cancer cell lines were obtained from the American Type Culture Collection (Manassas, Va., USA). D1 (normal endometrial) cells were obtained from menstrual flow under an Institutional Review Board-approved protocol as previously described [19]. The cells were maintained as monolayer cultures as previously described [20].

\section{Cell Proliferation Assay}

One day before treatment, approximately $1.5 \times 10^{4}$ cells were seeded per well in 96-well plates and allowed to attach overnight. Treatment groups consisted of 3-5 wells each. The cells were treated for 3 days with the test protein (either L-M, FP or mutated $\mathrm{FP}$ at $10^{-6} \mathrm{~mol} / \mathrm{l}$ or $\mathrm{FP}$ alone at $10^{-8}$ to $10^{-6} \mathrm{~mol} / \mathrm{l}$ ) or vehicle control. The media was changed on alternate days. At the end of the 3-day treatment period, the viable cell number was determined by MTS assay using the manufacturer's protocol (Promega, Madison, Wisc., USA).

\section{Data Analysis}

Multiple group comparisons were conducted using ANOVA and Student's t test for pair-wise comparisons. Group differences resulting in $p$ values of $<0.05$ were considered to be statistically significant.

\section{Results}

Inhibitory Effects of Fusion Protein, Mutated Fusion

Protein and L-Methioninase on A375 Skin, A2780

Ovary and MCF-7 Breast Cancer Cell Lines

The effect of the FP compared to L-M and a mutated FP $\left(10^{-6} \mathrm{~mol} / \mathrm{l}\right)$ on cell proliferation was examined in A375 skin, A2780 ovary and MCF-7 breast cancer cell lines as shown in figure 1 . Treatment with L-M alone produced a significant inhibition of cell proliferation in only the A2780 ovarian cancer cells $(\mathrm{p}<0.05)$. The FP with a mutated L-methioninase (M-FP) inhibited cell proliferation in all 3 cancer cell lines with the greatest effect $(80 \%$ inhibition) observed in the A2780 ovarian cancer cells $(\mathrm{p}<0.05)$. However, FP treatment produced a significant inhibitory effect, which was greater than that observed with either L-M or M-FP in all 3 cancer cell lines ( $\mathrm{p}<$ 0.05). 


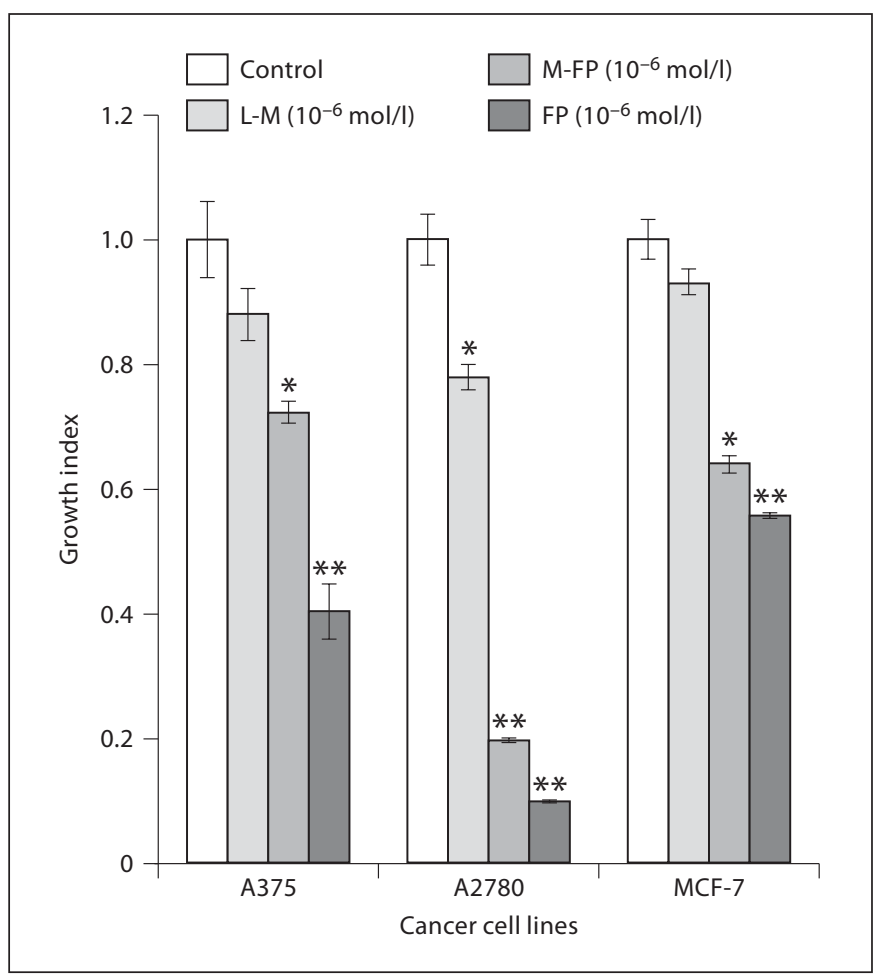

Fig. 1. Effect of L-methioninase (L-M), mutated L-methioninase (M-FP) or fusion protein (FP) after 3 days on the proliferation of A375 skin, A2780 ovarian and MCF-7 breast cancer cell lines. Each bar represents the mean \pm SEM of 3-5 observations for the treatment indicated relative to the mean control value. Significantly different than control: ${ }^{*} \mathrm{p}<0.05 ;{ }^{* *} \mathrm{p}<0.01$.

\section{Inhibitory Effect of the Fusion Protein on Ovarian}

Cancer Compared to a Normal Endometrial Cell Line

The effect of the FP over a concentration range of $10^{-8}$ to $10^{-6} \mathrm{~mol} / \mathrm{l}$ on $\mathrm{A} 2780$ ovarian cancer cells was compared to D1 normal endometrial cells as shown in figure 2. In this experiment, the FP produced a small but significant inhibition $(\mathrm{p}<0.05)$ of normal cell proliferation only at the highest concentration $\left(10^{-6} \mathrm{~mol} / \mathrm{l}\right)$, while the FP produced a small but statistically significant inhibition of A2780 ovarian cancer cells at $10^{-8}$ and $10^{-7} \mathrm{~mol} / \mathrm{l}$ and an $85 \%$ inhibition of cell proliferation at $10^{-6} \mathrm{~mol} / \mathrm{l}$.

\section{Inhibitory Effect of the Fusion Protein on Two}

Pancreatic Cancer Cell Lines

The FP produced a dose-related inhibition of cell proliferation in both the Paca-1 and HPAF-II human pancreatic cancer cell lines as illustrated in figure 3 . The FP inhibitory effect was significant at $10^{-7}$ and $10^{-6} \mathrm{~mol} / \mathrm{l}$ in both cancer cell lines $(\mathrm{p}<0.05)$.

A Fusion Protein for the Treatment of Cancer

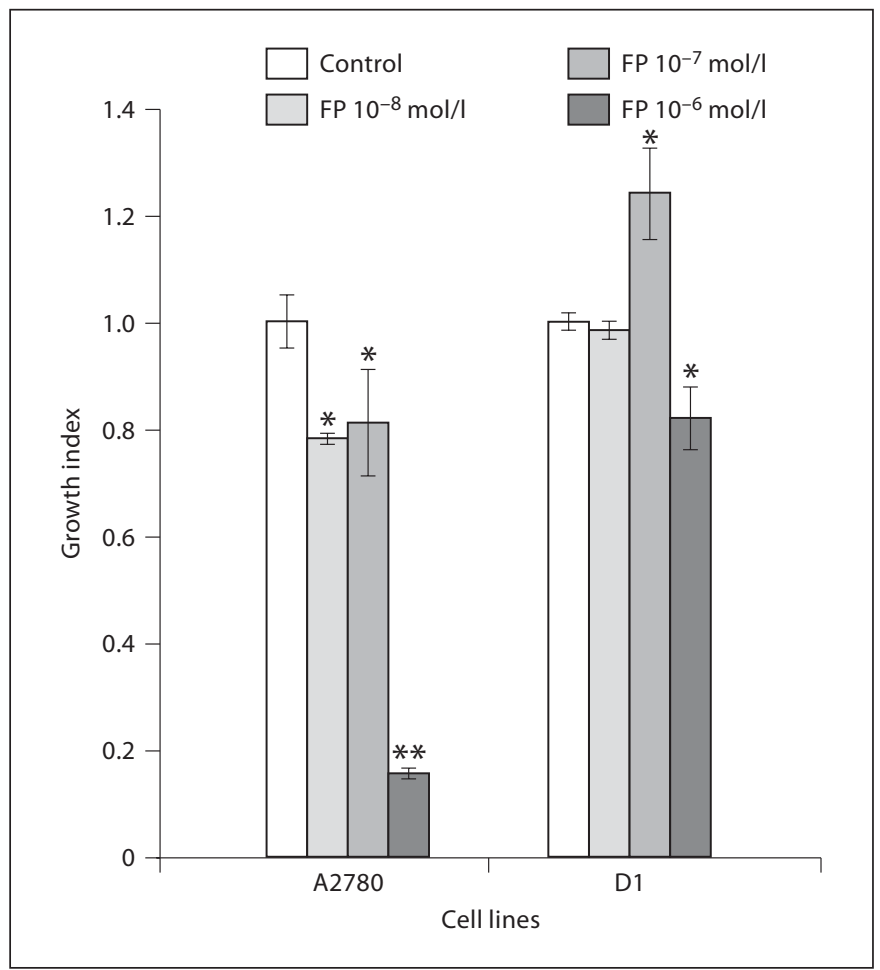

Fig. 2. Dose-response effect of the fusion protein (FP) after 3 days on the proliferation of A2780 ovarian cancer compared to D1 normal endometrial cells. Each bar represents the mean \pm SEM of 3-5 observations for the treatment indicated relative to the mean control value. Significantly different than control: ${ }^{*} \mathrm{p}<0.05$; ** $\mathrm{p}<0.01$.

\section{Discussion}

We have previously reported that this FP inhibited proliferation and migration of MCF-7 breast cancer cells both in cell culture and in nude mouse xenografts in vivo $[6,18]$. In order to determine the anti-cancer effects of the FP in other types of cancer, the present study examined its effects on the proliferation of human ovarian, skin, breast and pancreatic cancer cell lines (fig. 1). Interestingly, the A375 skin and the A2780 ovarian cancer cells appeared to be more sensitive to the inhibitory effects of FP than the MCF-7 breast cancer cells, while the L-M alone produced little or no inhibition. The methioninasemutated FP inhibited proliferation in all three cell lines, but was consistently less effective than the FP. These results indicate that targeting the methioninase to the urokinase receptor on the surface of the cancer cells produces much greater inhibition of cell proliferation than exposure of the cells to the same concentration of L-M in

Pharmacology 2009;84:271-275 


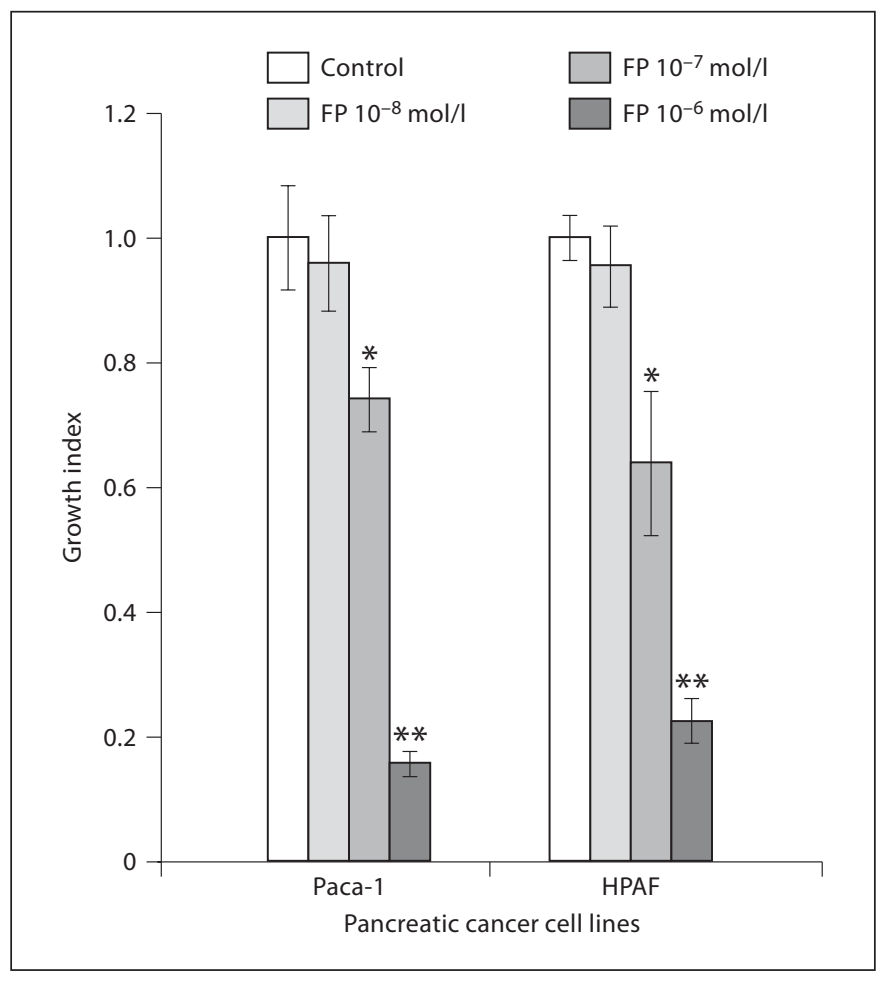

Fig. 3. Dose-response effect of fusion protein (FP) after 3 days on Paca-1 and HPAF pancreatic cancer cell lines. Each bar represents the mean \pm SEM of 3-5 observations for the treatment indicated relative to the mean control value. Significantly different than control: ${ }^{*} \mathrm{p}<0.05 ;{ }^{* *} \mathrm{p}<0.01$.

the culture media. The FP was designed to target L-M to the surface of the cancer cells in order to be more effective in reducing methionine uptake into the cancer cell compared to free $\mathrm{L}-\mathrm{M}$ in the cell media. It is not believed that bound FP is inherently more active than free L-M.

The results suggest that one mechanism of the inhibitory effects of the FP in the cell lines examined in this study is the methioninase-induced depletion of methionine available to the cancer cells. The use of ATF-FP to target L-M to urokinase receptors on the surface of cancer cells is advantageous because the ATF fragment of urokinase is not internalized. Internalization of the ATF protein does not occur since the catalytic domain of urokinase, which is required for internalization, is not present in the ATF protein [17]. We previously used immunocytochemistry to show that the FP, with methioninase either mutated or non-mutated, is localized on the cancer cell surface and that urokinase specifically displaces the FP from the cell surface [18].
While the mutated FP was less effective in inhibiting cell proliferation than the FP, it was significantly more effective than free L-M for all three cell lines $(\mathrm{p}<0.05)$, especially for A2780 ovarian and MCF-7 breast cancer cells. Thus, a major contribution of the effect of the FP on cancer cell proliferation is the blocking of the urokinase receptor. This blockade of the urokinase receptor should also reduce the metastasis of cancer cells in vivo, since receptor-bound urokinase is involved in the metastatic process.

The relative cytotoxicity of a cancer therapeutic agent is a major concern for any cancer therapy. The direct comparison of FP inhibitory effects on the growth of the normal endometrial cell line with an ovarian cancer cell line (fig. 2) indicates that this FP is much more toxic to the cancer cells. In general urokinase receptors in normal tissue are either absent or present at a much lower density than observed in cancer tissue. In addition, cancer cells are known to be much more sensitive to methioninedepletion than normal tissue $[1,2,21]$.

Carcinoma of the pancreas is highly metastatic and the fourth leading cause of cancer deaths in the United States. HPAF-II and Paca-1 are metastatic pancreatic cancer cell lines which are reported to be highly invasive [22]. Accordingly, the HPAF-II cell line has been employed by others to examine factors involved in pancreatic cancer progression and metastasis [23, 24]. Thus, these cells were employed in the present study to examine the influence of the FP on the viability of pancreatic cancer.

In conclusion, the $\mathrm{FP}$ was found to significantly reduce the proliferation of a variety of human cancer cell lines which represent cancers responsible for the majority of cancer mortality. Further, this FP was found to be significantly more effective than free L-M as an anticancer agent. Thus, the ATF-mediated targeting of methioninase activity to the surface of the cancer cells appears to be an effective approach and may serve as a therapeutic prototype for the development of a new class of targeted chemotherapeutic agents in the treatment of a very broad spectrum of carcinomas.

\section{Acknowledgements}

This study was supported in part by grants from the Oklahoma Center for the Advancement of Science and Technology, the Presbyterian Health Foundation, the OUHSC Cancer Institute, the American Cancer Society and NCI (RO1 CA106713). 


\section{References}

-1 Pavillard V, Drbal AA, Swaine DJ, Phillips RM, Double JA, Nicolaou A: Analysis of cellcycle kinetics and sulfur amino acid metabolism in methionine-dependent tumor cell lines; the effect of homocysteine supplementation. Biochem Pharmacol 2004;67:15871599.

-2 Hoffman RM: Methionine dependence in cancer cells - a review. In Vitro 1982;18:421428.

3 Kreis W, Hession C: Biological effects of enzymatic deprivation of L-methionine in cell culture and an experimental tumor. Cancer Res 1973;33:1866-1869.

-4 Tan Y, Xu M, Guo H, Sun X, Kubota T, Hoffman RM: Anticancer efficacy of methioninase in vivo. Anticancer Res 1996;16:39313936.

-5 Tan Y, Zavala J Sr, Han Q, Xu M, Sun X, Tan X, Magana R, Geller J, Hoffman RM: Recombinant methioninase infusion reduces the biochemical endpoint of serum methionine with minimal toxicity in high-stage cancer patients. Anticancer Res 1997;17:38573860.

6 Peron K, Jones TN, Gauthier SA, Nguyen TN, Zang XP, Barriere M, Preveraud D, Soliman CE, Harrison RG, Pento JT: Targeting of a novel fusion protein containing methioninase to the urokinase receptor to inhibit breast cancer cell migration and proliferation. Cancer Chemother Pharmacol 2003;52: 270-276.

7 Liu G, Shuman MA, Cohen RL: Co-expression of urokinase, urokinase receptor and PAI-1 is necessary for optimum invasiveness of cultured lung cancer cells. Int J Cancer 1995;60:501-506.

$>8$ Hollas W, Hoosein N, Chung LW, Mazar A, Henkin J, Kariko K, Barnathan ES, Boyd D: Expression of urokinase and its receptor in invasive and non-invasive prostate cancer cell lines. Thromb Haemost 1992;68:662666
9 Nielsen BS, Rank F, Illemann M, Lund LR, Dano K: Stromal cells associated with early invasive foci in human mammary ductal carcinoma in situ coexpress urokinase and urokinase receptor. Int J Cancer 2007;120: 2086-2095.

10 Beyer BC, Heiss MM, Simon EH, Gruetzner KU, Babic R, Jauch KW, Schildberg FW, Allgayer $\mathrm{H}$ : Urokinase system expression in gastric carcinoma: prognostic impact in an independent patient series and first evidence of predictive value in preoperative biopsy and intestinal metaplasia specimens. Cancer 2006;106:1026-1035.

11 Lindberg P, Larsson A, Nielsen BS: Expression of plasminogen activator inhibitor-1, urokinase receptor and laminin gamma-2 chain is an early coordinated event in incipient oral squamous cell carcinoma. Int J Cancer 2006;118:2948-2956.

12 Tan X, Egami H, Nozawa F, Abe M, Baba H Analysis of the invasion-metastasis mechanism in pancreatic cancer: involvement of plasmin(ogen) cascade proteins in the invasion of pancreatic cancer cells. Int J Oncol 2006;28:369-374.

13 Wang J, Guo F, Wei H, Dong J, Wu J: Expression of urokinase-type plasminogen activator receptor is correlated with metastases of lingual squamous cell carcinoma. Br J Oral Maxillofac Surg 2006;44:515-519.

14 Ellis V, Pyke C, Eriksen J, Solberg H, Dano $\mathrm{K}$ : The urokinase receptor: involvement in cell surface proteolysis and cancer invasion. Ann NY Acad Sci 1992;667:13-31.

15 Stoppelli MP, Corti A, Soffientini A, Cassani G, Blasi F, Assoian RK: Differentiationenhanced binding of the amino-terminal fragment of human urokinase plasminogen activator to a specific receptor on U937 monocytes. Proc Natl Acad Sci USA 1985;82: 4939-4943.

16 Appella E, Robinson EA, Ullrich SJ, Stoppelli MP, Corti A, Cassani G, Blasi F: The receptor-binding sequence of urokinase. A biological function for the growth-factor module of proteases. J Biol Chem 1987;262:4437-4440.
17 Cubellis MV, Wun TC, Blasi F: Receptor-mediated internalization and degradation of urokinase is caused by its specific inhibitor PAI-1. EMBO J 1990;9:1079-1085.

18 Zang XP, Palwai NR, Lerner MR, Brackett DJ, Pento JT, Harrison RG: Targeting a methioninase-containing fusion protein to breast cancer urokinase receptors inhibits growth and migration. Anticancer Res 2006; 26:1745-1751.

19 Kamelle S, Sienko A, Benbrook DM: Retinoids and steroids regulate menstrual phase histological features in human endometrial organotypic cultures. Fertil Steril 2002;78: 596-602.

20 Zang XP, Lerner MR, Dunn ST, Brackett DJ, Pento JT: Antisense KGFR oligonucleotide inhibition of KGF-induced motility in breast cancer cells. Anticancer Res 2003;23:49134919.

21 Cellarier E, Durando X, Vasson MP, Farges MC, Demiden A, Maurizis JC, Madelmont JC, Chollet P: Methionine dependency and cancer treatment. Cancer Treat Rev 2003;29: 489-499.

22 Rajasekaran SA, Gopal J, Espineda C, Ryazantsev S, Schneeberger EE, Rajasekaran AK: HPAF-II, a cell culture model to study pancreatic epithelial cell structure and function. Pancreas 2004;29:e77-e83.

-23 Guha S, Eibl G, Kisfalvi K, Fan RS, Burdick M, Reber H, Hines OJ, Strieter R, Rozengurt E: Broad-spectrum G protein-coupled receptor antagonist, [D-Arg1,D-Trp5,7,9, Leu11]SP: a dual inhibitor of growth and angiogenesis in pancreatic cancer. Cancer Res 2005;65:2738-2745.

24 Lin M, DiVito MM, Merajver SD, Boyanapalli M, van Golen KL: Regulation of pancreatic cancer cell migration and invasion by RhoC GTPase and caveolin-1. Mol Cancer 2005;4:21. 